\title{
Investigation of Physicochemical Properties of Some Monofloral Honeys in South Western Anatolia
}

\author{
Sukru Karatas (iD*1, Abdurrahman Aktumsek (iD)2, Mehmet Emin Duru (iD) 3 \\ ${ }^{1}$ Koycegiz Vocational School, Mugla Sitkı Kocman University, Mugla, Turkey \\ 2 Department of Biology, Science Faculty, Selcuk University, Konya, Turkey \\ ${ }^{3}$ Department of Chemistry, Science Faculty, Mugla Sitk1 Kocman University, Mugla, Turkey
}

\begin{abstract}
In this study, fourty monofloral honeys belonging to four sources (Chaste, thyme, citrus and heather) were obtained from South West Anatolia (Mugla, Aydin, Denizli and Antalya provinces). Firstly, pollen species of honeys were identified and categorized according to pollen concentrations. Then, physicochemical analyses of honey samples were carried out in terms of moisture, $\mathrm{pH}$, free acidity, conductivity, diastase, proline and sugar profile. Physicochemical results of moisture values $15.04-19.52 \%$, density values 1.32 $1.43\left(\mathrm{~g} / \mathrm{cm}^{3}\right)$, viscosity values $5.81-11.4925^{\circ} \mathrm{C} / \mathrm{Pa} . \mathrm{s}$, ash content $1.32-1.43 \%$, $\mathrm{pH}$ values 3.74-4.78, free acidity values $8.96-33.92 \mathrm{meq} / \mathrm{kg}$, conductivity values $0.15-1.41 \mu \mathrm{S} / \mathrm{cm}$, diastase numbers $3.44-17.26 \mathrm{~g} / 100 \mathrm{~g}$, proline contents $204.06-$ $1588.93 \mathrm{mg} / \mathrm{kg}$ and sugar contents (glucose+fructose) 62.02-74.90\%. It was shown that the results obtained when compared to TFC (Turkish Food Codex) and CODEX Alimentarius Commission Honey Standards were in line with the standards.
\end{abstract}

\section{ARTICLE HISTORY}

Received: March 12, 2019

Revised: July 03, 2019

Accepted: September 03, 2019

\section{KEYWORDS}

Physicochemical Analyses,

Pollen,

Monofloral Honey,

Sugar Profile

\section{INTRODUCTION}

Honey is probably known as the oldest natural sweetener product produced by honeybee (Apis mellifera) from different plants. Honey, a food product of natural sugars, is produced in almost all countries in the world and is widely consumed as a food source. Honey is highly preferred by consumers because of its wide range of uses such as nutritional quality, high energy values, sensory properties, and medical properties. However, honey cannot be considered to be exactly a food in the diet, but it can take part in nutrition as an additional nutritional supplement [1]. Honey is divided into the two main groups (flower and blossom), according to the source of nectar collected by honey bee. The general source of flower honey is the nectar of flowers and the source of blossom honey is from excretions of plant sucking insects (Hemiptera) in the living parts of plants or secretions of living parts of plants [2]. Honey has a high proportion of carbohydrates, $85-95 \%$ of which is composed of glucose and fructose. The fructose ratio of honey is higher than glucose. There are minerals, vitamins, enzymes and aroma in honey as well. 
Melissopalynology analysis is the most widely used way to determine the honey's geographical and botanical origin [3]. If the honey consists of a single plant source or contains dominant pollen $(>45 \%)$, it is called monofloral honey $[1,4,5]$. Monofloral honeys are characterized by their inclusion of parameters such as $\mathrm{pH}$, water content, sugar, color and electrical conductivity [6-8]. The determination of these parameters gives us information about the origin of monofloral honeys, botanical type, freshness of honey and honey source [2].

South West Anatolia region, with high potential for production and export levels increasing day by day, is the biggest location in production of flower honey in Turkey. However, the physicochemical information which can give information about the commercial value of this region's trade and its medicinal use is very insufficient in Turkey.

The aim of this study is to determine the botanical origins and physicochemical qualities of the monofloral species supplied from the South West Anatolia region in Turkey.

\section{MATERIAL AND METHODS}

In this study, fourty monofloral honey samples belonging to four sources (chaste, thyme, citrus and heather) produced in South West Anatolia (Mugla, Antalya, Aydin and Denizli province) were collected from members of Honey Producer Association. The collected honey samples were coded in $850 \mathrm{~mL}$ glass jars and stored in dark and room conditions until the analyses were done. The codes of used honey samples in this study were given in Table 1 . Firstly, pollen analysis of honey samples were made and categorized according to pollen concentration. Then, physicochemical analysis of honey samples was carried out in terms of moisture, $\mathrm{pH}$, free acidity, conductivity, diastase enzyme, proline and total sugars in honey by following the standard methods of the Association of Official Analytical Chemists [9].

\subsection{Determination of Water Content (Moisture)}

The moisture content of the honey was determined by using the refraction index obtained at $20{ }^{\circ} \mathrm{C}$ on the digital type refractometer (Mettler Toledo - RM 40) and using the moisture calculation chart [9].

\subsection{Density}

Honey samples' density was determined according to Bogdanov (1995) [10]. Consequently, it was calculated by comparing the density of the tape measure filled with 10 $\mathrm{mL}$ of honey to the density obtained by filling the same tape with distilled water.

\subsection{Viscosity}

$50 \mathrm{~g}$ of honey sample was weighed and incubated for one hour at $25^{\circ} \mathrm{C}$ in a water bath. The viscosity of honey samples was measured at $25 \pm 0.5^{\circ} \mathrm{C}$ with digital thermostat rotational viscometer [11-13].

\subsection{Ash content}

Ash content in honey samples (AOAC, 1995) [9] was made according to the method. Accordingly, approximately $3 \mathrm{~g}$ of honey from each sample was weighed and burned in an ash oven at $900{ }^{\circ} \mathrm{C}$, the residue was weighed on a sensitive balance and the ash content of the samples was calculated as a percentage. 
Table 1. The codes, origin, region and harvest year of honey samples

\begin{tabular}{|c|c|c|c|c|}
\hline Code No & Origin & Province & Town & Harvest Year \\
\hline $\mathrm{HC} 1$ & Chaste & Aydin & Cine & 2017 \\
\hline $\mathrm{HC} 2$ & Chaste & Aydin & Cine & 2017 \\
\hline HC3 & Chaste & Aydin & Cine & 2017 \\
\hline $\mathrm{HC} 4$ & Chaste & Aydin & Cine & 2017 \\
\hline HK1 & Chaste & Aydin & Kocarli & 2017 \\
\hline HK2 & Chaste & Aydin & Kocarli & 2017 \\
\hline HS1 & Chaste & Aydin & Soke & 2017 \\
\hline HS2 & Chaste & Aydin & Soke & 2017 \\
\hline HS3 & Chaste & Aydin & Soke & 2017 \\
\hline KD1 & Thyme & Mugla & Datca & 2017 \\
\hline $\mathrm{KD} 2$ & Thyme & Mugla & Datca & 2017 \\
\hline KD3 & Thyme & Mugla & Datca & 2017 \\
\hline KD4 & Thyme & Mugla & Datca & 2017 \\
\hline KD5 & Thyme & Mugla & Datca & 2017 \\
\hline KK1 & Thyme & Denizli & Tavas & 2017 \\
\hline KK2 & Thyme & Denizli & Tavas & 2017 \\
\hline KU1 & Thyme & Mugla & Ula & 2017 \\
\hline KU2 & Thyme & Mugla & Ula & 2017 \\
\hline KU3 & Thyme & Mugla & Ula & 2017 \\
\hline NF1 & Citrus & Antalya & Finike & 2017 \\
\hline NF2 & Citrus & Antalya & Finike & 2017 \\
\hline NF3 & Citrus & Antalya & Finike & 2017 \\
\hline NF4 & Citrus & Antalya & Finike & 2017 \\
\hline NF5 & Citrus & Antalya & Finike & 2017 \\
\hline NK1 & Citrus & Mugla & Koycegiz & 2017 \\
\hline $\mathrm{NK} 2$ & Citrus & Mugla & Koycegiz & 2017 \\
\hline NK3 & Citrus & Mugla & Koycegiz & 2017 \\
\hline NK4 & Citrus & Mugla & Koycegiz & 2017 \\
\hline NK5 & Citrus & Mugla & Koycegiz & 2017 \\
\hline NK6 & Citrus & Mugla & Koycegiz & 2017 \\
\hline NK7 & Citrus & Mugla & Koycegiz & 2017 \\
\hline NK8 & Citrus & Mugla & Koycegiz & 2017 \\
\hline PC1 & Heather & Aydin & Cine & 2017 \\
\hline $\mathrm{PC} 2$ & Heather & Aydin & Cine & 2017 \\
\hline PD1 & Heather & Mugla & Datca & 2017 \\
\hline PD2 & Heather & Mugla & Datca & 2017 \\
\hline PD3 & Heather & Mugla & Datca & 2017 \\
\hline PK1 & Heather & Aydin & Kocarli & 2017 \\
\hline PK2 & Heather & Aydin & Kocarli & 2017 \\
\hline PK3 & Heather & Aydin & Kocarli & 2017 \\
\hline
\end{tabular}




\subsection{Pollen Analysis}

The pollen experiment gives important information about the origin of honey. Pollen analysis was applied with the method adopted by International Beekeeping Authorities [16, 17, 18]. When pollen species of honey sample are examined, it is classified according to percentages. If the pollens concentration of a plant is more than $45 \%[15,24]$, it is assumed that the examined honey consists of a single source [7].

The honey kept in a glass jar was first mixed with a glass bag and dispersed homogeneously. $10 \mathrm{~g}$ of this honey sample was transferred to a centrifuge tube and $20 \mathrm{~mL}$ purified water was added. This solution was centrifuged for 30 minutes at $4000 \mathrm{rpm}$ and the solution pollen in the solution in the tube was thoroughly precipitated. The bottom of the precipitated honey was then transferred onto a slide. The slide was heated to $30-40{ }^{\circ} \mathrm{C}$ and homogenous distribution of the pollen in the basic fucsin glycerin gelatin was achieved using a needle after the gelatin melt. The amount of pollen in the honey was determined with Olympus CX-31 brand microscope and the number of pollen in each preparation was calculated as a percentage. The fact that the pollens used in this study contain pollen densities of $45-94 \%$ indicates that they are monofloral [15].

\subsection{Determination of $\mathrm{pH}$ and Free Acidity}

$\mathrm{pH}$ measurement of honey samples was made with Mettler Toledo Seven Multi pH Meter. The titrimetric method was used to determination of free acidity. The titrimetric method: $10 \mathrm{~g}$ honey sample was dissolved in $75 \mathrm{~mL}$ of carbondioxide free-distilled water in a beaker and $\mathrm{pH}$ was recorded by means of immersing the $\mathrm{pH}$ electrodes in the solution. The obtained solution titrated with $0.1 \mathrm{~N} \mathrm{NaOH}$ to $\mathrm{pH} 8.30$ and also blind trial was made under the same conditions. The results were given as meq/ $\mathrm{kg}$ [9].

\subsection{Determination of Electrical Conductivity}

The determination of the electrical conductivity of honey is principally based on the measurement of the electrical resistance. Measurements were made with the Mettler Toledo brand, Seven Multi model conductor. For the measurement of the conductivity, $20 \mathrm{~g}$ of honey was weighed in a $100 \mathrm{~mL}$ beaker. After dissolving with some distilled water, it was taken into a $100 \mathrm{~mL}$ volumetric flask and completed with distilled water. After taking $40 \mathrm{~mL}$ of this honey solution to a beaker, the temperature was adjusted to $20{ }^{\circ} \mathrm{C}$ and measured by a conductor [9].

\subsection{Diastase Activity}

To determine the diastase number, $1 \mathrm{~g}$ of honey was put into $100 \mathrm{~mL}$ volumetric flask and $5 \mathrm{~mL}$ of samples were put into each of test tubes. The first test tube was placed in the acetate buffer only as a blind test and the Phadepas tablet was placed in each test tube and allowed to stay in a water bath at $40{ }^{\circ} \mathrm{C}$ for 15 minutes. At the end of this period, $1 \mathrm{~mL}$ of a $0.5 \mathrm{M} \mathrm{NaOH}$ solution was added and the absorbance value of each tube was measured at $620 \mathrm{~nm}$ wavelength with UV-Spectrophotometer (Agilent, Cary-60 model) in $1 \mathrm{~cm}$ light path cuvettes [9].

\subsection{Proline}

The protein content of honey is usually determined by the proline specification and the spectrophotometric method is used to determine the amount of proline [9]. The reaction of proline was made with 3\% ninhydrin in a formic acid medium and absorbance of the result product was measured spectrophotometrically at $510 \mathrm{~nm}$ wavelength (Agilent, Cary-60 model).

\subsection{Sugar Analysis}

Honey's glucose and fructose ratio and amount of sucrose were determined by means of sugar analysis. The sugar analysis was applied according to method specified by AOAC, 2005 [9]. Measurements were made on HPLC (Agilent-1200 Infinity) instrument. In accordance with 
the method, $5 \mathrm{k}$ silica gel filled column was used. Refractive Index Detector (RID) was used as the detector. HPLC operating conditions are shown below.
Column
: Zorbax $\left(\mathrm{NH}_{2}\right) 4.6 \times 250 \mathrm{~mm} 5 \mu \mathrm{m}$ (Agilent 880952-708)
Mobile Phase (Isocratic system): $\left(\mathrm{CH}_{3} \mathrm{CN}: \mathrm{H}_{2} \mathrm{O}\right)(83: 17, \mathrm{v} / \mathrm{v})$ for analytical chromatography
Flow rate
$: 1 \mathrm{~mL} / \mathrm{min}$
Column temperature
$:\left(30{ }^{\circ} \mathrm{C}\right)$
Detector (RID) temperature $\quad:\left(35^{\circ} \mathrm{C}\right)$
Injection volume
$: 10 \mu \mathrm{L}$

\section{RESULTS and DISCUSSION}

\subsection{Moisture Content}

The amount of moisture in honey is the best indicator of the honey's maturity and shelf life. The amount of moisture in honey depends on environmental conditions and manipulation during the harvesting period. It may also vary with season and year [21]. If the moisture value of honey is high, it indicates that honey is harvested before maturation [2]. In this study, the values of moisture content were found between $15.04 \%$ and $19.00 \%$ range in chaste honey samples, between $15.16 \%$ and $19.12 \%$ range in thyme honey samples, between $16.12 \%$ and $18.76 \%$ range in citrus honey samples and between $16.24 \%$ and $19.52 \%$ range in heather honey samples (Table $2 \mathrm{a}, 2 \mathrm{~b}, 2 \mathrm{c}$ and $2 \mathrm{~d}$ ). When the total of 40 honeys was considered, the minimum moisture value was found to be $15.04 \%$ and the maximum moisture value was found to be $19.52 \%$.

The values of moisture content of our samples were found to be under the upper limit of $20 \%$, previously reported for different kinds of floral honeys [23].

\subsection{Density}

The density of honey is an important physical property affecting the stratification in honey. The honey's density is slightly higher than that of water, although it depends on the moisture content of the honey [24]. The core densities of 4 different honey subject to this study are in the range of $1.32-1.43 \mathrm{~g} / \mathrm{cm}^{3}$. When the average of the core density of each monofloral honey is calculated; respectively, 1.37 in chaste honey, 1.38 in thyme honey, 1.36 in citrus honey and $1.36\left(\mathrm{~g} / \mathrm{cm}^{3}\right)$ in heather honey. These values meet the $1.43\left(\mathrm{~g} / \mathrm{cm}^{3}\right)$ limit set by the TFC and CODEX Alimentarius Standards $(2001)$ [4, 30].

\subsection{Viscosity}

Viscosity is defined as the resistance of liquid molecules to flow due to frictional force. Honey is a food with high viscosity due to its components and low moisture content. As the temperature increases, the viscosity of honey decreases $[11,12]$. In a study investigating the physicochemical properties of honey, it was reported that the viscosity of pine, fir, cotton, orange, sunflower and thyme honey ranged between 2.54-23.4 (P.as) [13]. In another study of the various condiments produced in Turkey, viscosity values of results obtained for samples of 1.77-(11:38) to range Pa.s range, the lowest of clover honey, while the cedar honey has been reported to have the highest viscosity [12]. In this study, the viscosity results of the honeys we studied are in agreement with the results given in the literature.

\subsection{Ash Content}

As can be seen Table 2a, 2b, $2 \mathrm{c}$ and $2 \mathrm{~d}$, the ash content of the honey we work on varies between $0.09 \%$ and $0.72 \%$ by weight. The lowest amount was calculated in citrus honey, while the highest ash content was calculated in purple honey. These values are consistent with the data in the literature [14]. 


\subsection{Pollen Analysis}

In this study, density of pollen were found between $47 \%$ and $85 \%$ range in chaste honey samples, between $48 \%$ and $94 \%$ range in thyme honey samples, between $48 \%$ and $92 \%$ range in citrus honey samples and between $50 \%$ and $90 \%$ range in heather honey samples.

According to the obtained results has been proved that all the used honey in the study shows the monofloral honey feature (more than 45\% dominant pollen). The pollen concentrations of the honey samples and microscopic images of pollen types in this study are given in Table 1 and in Figure 1.
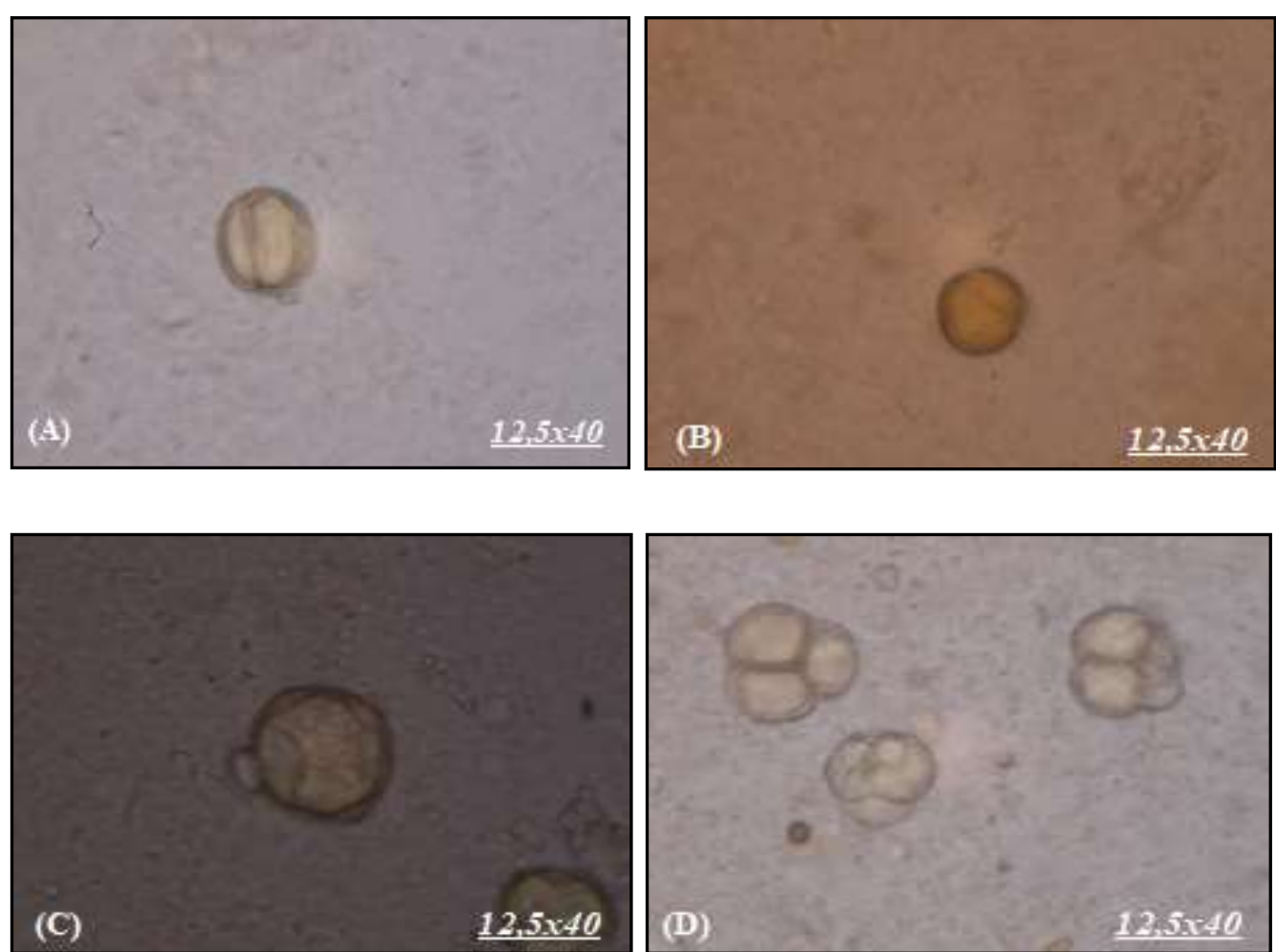

Figure 1. Microscopic Images of Pollen Types (A) Chaste (Verbenaceae-Vitex agnus-castus L.); (B) Thyme (Lamiaceae-Thymus subs.); (C) Citrus (Rutaceae-Citrus subs.); (D) Heather (Ericaceae-Erica subs.)

\section{6. $\mathrm{pH}$ and Free Acidity}

The amount of acid contributes particularly to the unique taste of monofloral honeys. Having a low $\mathrm{pH}$ of honey is important because it prevents the presence and growth of microorganisms in the honey. Having a low $\mathrm{pH}$ allows the honey to blend easily with other known food products [26, 27].

In this study, the $\mathrm{pH}$ values of chaste honey samples were found to be between 3.80 and 4.23 range, between 3.96 and 4.75 range in thyme honey samples, between 3.74 and 4.59 range in citrus honey samples and between 3.83 and 4.78 range in heather honey samples (Table 2a, $2 \mathrm{~b}, 2 \mathrm{c}, 2 \mathrm{~d})$. The $\mathrm{pH}$ values of the studied honey samples ranged from 3.74 to 4.78 range. These values are in accordance with acceptable range for honey [1] and similar to those obtained with others Turkish honeys [28].

The free acidity of chaste honey samples was ranged from 14.83 to $26.91 \mathrm{meq} / \mathrm{kg}$, thyme honey samples from 19.88 to $33.92 \mathrm{meq} / \mathrm{kg}$, citrus honey samples from 8.96 to $27.92 \mathrm{meq} / \mathrm{kg}$, heather honey samples from 15.95 to $31.82 \mathrm{meq} / \mathrm{kg}$. According to CODEX Alimentarius, the 
free acidity value of a honey cannot be more than $50 \mathrm{meq} / \mathrm{kg}$ of the high-quality honey, indicating the absence of undesirable fermentation. The obtained results of free acidity are given in the Table 2a, 2b, 2c and 2d and found to be compatible with CODEX Alimentarius [4] and agreement with data reported for Silva et al. [9].

\subsection{Electrical Conductivity}

Electrical conductivity has an important role in determining the source of honey. The electrical conductivity of honey is related with organic acids, proteins, sugars and mineral substances in the honey [7, 27]. According to the TFC, the conductivity values of the honeydew honey should be above $0.8 \mu \mathrm{S} / \mathrm{cm}$ and the conductivity values of the flower honeys should be below $0.8 \mu \mathrm{S} / \mathrm{cm}$. If the flower honey is mixed with the honeydew honey, the conductivity values may be above $0.8 \mu \mathrm{S} / \mathrm{cm}$.

The electrical conductivity results of analyzed honey samples are given in Table $2 a, 2 b$, $2 \mathrm{c}$ and $2 \mathrm{~d}$. The electrical conductivity of chaste honey samples were ranged from 0.27 to 0.76 $\mu \mathrm{S} / \mathrm{cm}$, thyme honey samples from 0.82 to $1.50 \mu \mathrm{S} / \mathrm{cm}$, citrus honey samples from 0.15 to 0.71 $\mu \mathrm{S} / \mathrm{cm}$, heather honey samples from 0.83 to $1.41 \mu \mathrm{S} / \mathrm{cm}$. When the obtained results are evaluated, chaste and citrus honeys are found below $0.8 \mu \mathrm{S} / \mathrm{cm}$ and above thyme and heather honeys $0.8 \mu \mathrm{S} / \mathrm{cm}$. The reason why thyme and heather honeys are greater than $0.8 \mu \mathrm{S} / \mathrm{cm}$, is that there are thyme species of Thymbra spicata, Origanum onites and Thymus cilicicus in the area where thyme samples are collected. These three types of thyme are also consumed as spices and tea. There are intense pine trees in the area where thyme and heather plants are found. Since the collection of samples coincided with the early pine bark period, the sporophyte obtained by the Marcellina bug was observed in the palynological analysis carried out in small quantities except pollen. The mixing of these secretions with thyme and heather honeys caused an increase in the conductivity level.

\subsection{Diastase Number}

The diastase number is important for the quality of honey because the diastase enzyme is the honey bee transits from its body to the nectar during processing. Diastase is an enzyme secreted from the bottom of the honey bee and plays a role in the digestion of starch [29]. According to CODEX Alimentarius standards, the minimum diastase number should be at least 8. Despite this, the minimum diastase number of low natural enzyme content e.g. citrus honeys should be at least 3 according to the TFC [30] and Kuc et al. [31].

The results of the lowest diastase number chaste, thyme, heather and citrus honey were found to be $8.06,8.11,8.07,3.44$, respectively. When the results obtained are evaluated, it was found that these values comply with previous studies [31,32] and worldwide accepted standards (CODEX Alimentarious and TFC). Diastase numbers of honey samples were measured and the values found are given in Table $2 \mathrm{a}, 2 \mathrm{~b}, 2 \mathrm{c}$ and $2 \mathrm{~d}$.

\subsection{Proline}

The honey contains 20 kinds of amino acids. Proline is the most widely present amino acid in honey, in comparison with other amino acids. The amount of proline in the honey is indicative of the purity of honey. The level of the proline is more closely related to the performance of the bees [33,27].

The values of proline content are given in Table $2 a, 2 b, 2 c, 2 d$ and it is found that thyme honeys are $1588.93 \mathrm{mg} / \mathrm{kg}$ higher than other monofloral honey samples in terms of proline amount and the citrus samples were found to have the lowest proline content of $204.06 \mathrm{mg} / \mathrm{kg}$. According to TFC and Bogdanov et al. [34], minimum acceptable value proline content for genuine honey is $180 \mathrm{mg} / \mathrm{kg}$ in control laboratories. The obtained data of our studies are in accordance with the TFC and the other studies. 
Table 2a. Physicochemical Results of Chaste Honey Samples

\begin{tabular}{ccccccccccc}
\hline Code No & $\begin{array}{c}\text { Moisture } \\
(\%)\end{array}$ & $\mathrm{pH}$ & $\begin{array}{c}\text { Free acidity } \\
(\mathrm{meq} / \mathrm{kg})\end{array}$ & $\begin{array}{c}\text { Conductivity } \\
(\mu \mathrm{S} / \mathrm{cm})\end{array}$ & & $\begin{array}{c}\text { Diastase } \\
(\mathrm{mg} / \mathrm{kg})\end{array}$ & $\begin{array}{c}\text { Polen } \\
\text { density } \\
(\%)\end{array}$ & $\begin{array}{c}\text { Viscosity } \\
\left(25^{\circ} \mathrm{C} / \mathrm{Pa} . \mathrm{s}\right)\end{array}$ & $\begin{array}{c}\text { Ash } \\
\text { content } \\
(\%)\end{array}$ & $\begin{array}{c}\text { Density } \\
\left(\mathrm{g} / \mathrm{cm}^{3}\right)\end{array}$ \\
\hline $\mathrm{HC} 1$ & 18.08 & 4.02 & 18.89 & 0.76 & 12.51 & 859.59 & 55 & 7.39 & 0.31 & 1.34 \\
$\mathrm{HC} 2$ & 17.16 & 4.23 & 22.85 & 0.73 & 14.77 & 772.36 & 47 & 8.06 & 0.27 & 1.36 \\
$\mathrm{HC} 3$ & 16.90 & 3.86 & 17.87 & 0.28 & 17.26 & 816.95 & 72 & 8.42 & 0.19 & 1.38 \\
$\mathrm{HC} 4$ & 18.56 & 3.87 & 20.95 & 0.51 & 8.06 & 643.89 & 80 & 7.15 & 0.34 & 1.33 \\
$\mathrm{HK} 1$ & 15.40 & 4.16 & 24.71 & 0.32 & 9.38 & 515.29 & 85 & 8.83 & 0.28 & 1.42 \\
$\mathrm{HK} 2$ & 19.00 & 3.97 & 26.91 & 0.49 & 9.18 & 460.44 & 60 & 6.62 & 0.36 & 1.32 \\
$\mathrm{HS} 1$ & 18.52 & 3.99 & 16.80 & 0.38 & 10.80 & 457.11 & 68 & 7.11 & 0.23 & 1.33 \\
$\mathrm{HS} 2$ & 16.40 & 3.80 & 14.83 & 0.27 & 10.05 & 508.77 & 48 & 8.56 & 0.35 & 1.39 \\
$\mathrm{HS} 3$ & 15.04 & 4.03 & 16.92 & 0.35 & 10.97 & 523.39 & 51 & 9.07 & 0.22 & 1.43 \\
\hline
\end{tabular}

Table 2b. Physicochemical Results of Thyme Honey Samples

\begin{tabular}{ccccccccccc}
\hline Code No & $\begin{array}{c}\text { Moisture } \\
(\%)\end{array}$ & $\mathrm{pH}$ & $\begin{array}{c}\text { Free acidity } \\
(\mathrm{meq} / \mathrm{kg})\end{array}$ & $\begin{array}{c}\text { Conductivity } \\
(\mu \mathrm{S} / \mathrm{cm})\end{array}$ & Diastase & $\begin{array}{c}\text { Proline } \\
(\mathrm{mg} / \mathrm{kg})\end{array}$ & $\begin{array}{c}\text { Polen } \\
\text { density } \\
(\%)\end{array}$ & $\begin{array}{c}\text { Viscosity } \\
\left(25^{\circ} \mathrm{C} / \mathrm{Pa} . \mathrm{s}\right)\end{array}$ & $\begin{array}{c}\text { Ash } \\
\text { content } \\
(\%)\end{array}$ & $\begin{array}{c}\text { Density } \\
\left(\mathrm{g} / \mathrm{cm}^{3}\right)\end{array}$ \\
\hline $\mathrm{KD} 1$ & 17.16 & 3.96 & 21.84 & 0.82 & 8.11 & 682.50 & 60 & 9.88 & 0.27 & 1.37 \\
$\mathrm{KD} 2$ & 16.76 & 4.31 & 27.92 & 1.22 & 8.76 & 912.47 & 78 & 10.45 & 0.18 & 1.38 \\
$\mathrm{KD} 3$ & 16.04 & 4.04 & 27.82 & 0.81 & 8.94 & 1110.08 & 90 & 10.63 & 0.31 & 1.39 \\
$\mathrm{KD} 4$ & 15.53 & 4.57 & 21.82 & 1.07 & 11.82 & 588.65 & 70 & 10.97 & 0.20 & 1.42 \\
$\mathrm{KD} 5$ & 16.87 & 4.74 & 19.88 & 1.50 & 15.40 & 470.13 & 55 & 10.37 & 0.26 & 1.38 \\
$\mathrm{KK} 1$ & 15.60 & 4.17 & 28.68 & 0.92 & 11.22 & 1244.16 & 50 & 10.95 & 0.33 & 1.42 \\
$\mathrm{KK} 2$ & 17.68 & 4.55 & 22.91 & 1.17 & 9.73 & 744.80 & 85 & 9.15 & 0.19 & 1.36 \\
$\mathrm{KU} 1$ & 17.68 & 4.31 & 28.89 & 0.96 & 11.74 & 810.66 & 53 & 9.18 & 0.21 & 1.36 \\
KU2 & 19.12 & 4.75 & 21.88 & 1.27 & 8.66 & 761.65 & 94 & 8.35 & 0.17 & 1.32 \\
KU3 & 15.16 & 4.43 & 33.92 & 1.31 & 8.25 & 1588.93 & 48 & 11.49 & 0.25 & 1.43 \\
\hline
\end{tabular}

Table 2c. Physicochemical Results of Citrus Honey Samples

\begin{tabular}{|c|c|c|c|c|c|c|c|c|c|c|}
\hline Code No & $\begin{array}{c}\text { Moisture } \\
\text { (\%) }\end{array}$ & $\mathrm{pH}$ & $\begin{array}{l}\text { Free acidity } \\
\text { (meq/kg) }\end{array}$ & $\begin{array}{l}\text { Conductivity } \\
(\mu \mathrm{S} / \mathrm{cm})\end{array}$ & Diastase & $\begin{array}{l}\text { Proline } \\
(\mathrm{mg} / \mathrm{kg})\end{array}$ & $\begin{array}{c}\text { Polen } \\
\text { density } \\
(\%)\end{array}$ & $\begin{array}{c}\text { Viscosity } \\
\left(25^{\circ} \mathrm{C} / \text { Pa.s }\right)\end{array}$ & $\begin{array}{c}\text { Ash } \\
\text { content } \\
(\%)\end{array}$ & $\begin{array}{l}\text { Density } \\
\left(\mathrm{g} / \mathrm{cm}^{3}\right)\end{array}$ \\
\hline NF1 & 17.24 & 3.74 & 12.88 & 0.23 & 7.44 & 340.58 & 48 & 6.92 & 0.11 & 1.36 \\
\hline NF2 & 17.04 & 3.75 & 15.88 & 0.24 & 7.01 & 435.05 & 55 & 7.03 & 0.17 & 1.37 \\
\hline NF3 & 16.12 & 3.99 & 10.88 & 0.20 & 3.60 & 205.09 & 95 & 8.14 & 0.15 & 1.40 \\
\hline NF4 & 16.20 & 4.59 & 8.96 & 0.71 & 5.02 & 300.76 & 60 & 8.09 & 0.09 & 1.39 \\
\hline NF5 & 17.26 & 4.07 & 10.99 & 0.19 & 3.62 & 216.38 & 92 & 6.93 & 0.19 & 1.36 \\
\hline NK1 & 16.97 & 4.32 & 11.92 & 0.45 & 4.28 & 315.47 & 80 & 7.72 & 0.13 & 1.37 \\
\hline NK2 & 16.97 & 4.45 & 11.91 & 0.56 & 4.10 & 325.05 & 77 & 7.74 & 0.15 & 1.37 \\
\hline NK3 & 18.24 & 4.24 & 23.72 & 0.68 & 6.29 & 541.13 & 50 & 5.96 & 0.12 & 1.34 \\
\hline NK4 & 17.16 & 4.16 & 10.87 & 0.27 & 4.01 & 357.33 & 87 & 6.95 & 0.14 & 1.36 \\
\hline NK5 & 18.72 & 4.23 & 11.97 & 0.26 & 3.44 & 231.84 & 48 & 5.87 & 0.18 & 1.33 \\
\hline NK6 & 17.60 & 3.93 & 20.91 & 0.29 & 6.24 & 633.26 & 65 & 6.75 & 0.20 & 1.36 \\
\hline NK7 & 18.76 & 4.13 & 27.92 & 0.58 & 11.22 & 984.96 & 72 & 5.81 & 0.14 & 1.33 \\
\hline NK8 & 17.26 & 4.14 & 10.88 & 0.15 & 5.45 & 204.06 & 60 & 9.94 & 0.16 & 1.38 \\
\hline
\end{tabular}


Table 2d. Physicochemical Results of Heather Honey Samples

\begin{tabular}{|c|c|c|c|c|c|c|c|c|c|c|}
\hline $\begin{array}{l}\text { Code } \\
\text { No }\end{array}$ & $\begin{array}{c}\text { Moisture } \\
(\%)\end{array}$ & $\mathrm{pH}$ & $\begin{array}{c}\text { Free acidity } \\
(\mathrm{meq} / \mathrm{kg})\end{array}$ & $\begin{array}{c}\text { Conductivity } \\
(\mu \mathrm{S} / \mathrm{cm})\end{array}$ & Diastase & $\begin{array}{l}\text { Proline } \\
(\mathrm{mg} / \mathrm{kg})\end{array}$ & $\begin{array}{c}\text { Polen } \\
\text { density } \\
(\%)\end{array}$ & $\begin{array}{c}\text { Viscosity } \\
\left(25^{\circ} \mathrm{C} / \mathrm{Pa} . \mathrm{s}\right. \\
) \\
\end{array}$ & $\begin{array}{c}\text { Ash } \\
\text { content } \\
(\%)\end{array}$ & $\begin{array}{l}\text { Density } \\
\left(\mathrm{g} / \mathrm{cm}^{3}\right)\end{array}$ \\
\hline $\mathrm{PC} 1$ & 17.26 & 3.83 & 31.82 & 0.83 & 8.07 & 758.53 & 56 & 9.28 & 0.39 & 1.37 \\
\hline $\mathrm{PC} 2$ & 17.60 & 4.22 & 25.93 & 0.99 & 14.33 & 787.82 & 66 & 8.75 & 0.54 & 1.36 \\
\hline PD1 & 18.18 & 4.78 & 15.95 & 1.41 & 10.15 & 496.73 & 82 & 8.41 & 0.43 & 1.34 \\
\hline PD2 & 16.24 & 4.05 & 17.82 & 0.80 & 12.33 & 789.46 & 50 & 10.48 & 0.72 & 1.39 \\
\hline PD3 & 16.52 & 4.72 & 21.82 & 1.39 & 10.02 & 569.53 & 70 & 10.15 & 0.69 & 1.38 \\
\hline PK1 & 18.86 & 4.50 & 18.87 & 0.88 & 9,81 & 647.16 & 77 & 7.34 & 0.41 & 1.33 \\
\hline PK2 & 19.52 & 4.47 & 19.89 & 0.92 & 11.13 & 843.47 & 90 & 7.11 & 0.47 & 1.32 \\
\hline PK3 & 17.68 & 4.62 & 21.78 & 1.25 & 14.02 & 664.01 & 60 & 8.29 & 0.36 & 1.36 \\
\hline
\end{tabular}

\subsection{Sugar Analysis}

The content of honey sugar depends on the botanical origin. The sucrose in the form of nectar is produced by the bees and is formed by enzymatic hydrolysis to provide glucose and fructose formation [35]. Glucose and fructose are the major constituents of honey. Fructose is always the most important sugar because fructose is sweeter than glucose. In our study, fructose concentration was higher than glucose concentration in all honey samples studied and also fructose/glucose ratio affects the taste of honey. According to CODEX Alimentarious and TFC, it was determined that the amount of sucrose should be at most $5 \mathrm{~g} / 100 \mathrm{~g}$ and the concentration of fructose and glucose in honey samples should be at least $60 \%$.

The results of our honey samples, the amount of sucrose was found to match the determined limits and it was determined that the glucose and fructose concentrations of all honey samples were higher than $60 \%$ and the sugar content (glucose + fructose) was between 62.02 and $74.90 \%$ and the F/G ratio in the honey samples evaluated ranged between 1.1 and 1.5 (Table 3), which is close to the ratio found by de Sousa et al. [36] and TFC in honey samples.

Table 3. Results of Sugar Profile

\begin{tabular}{cccccc}
\hline Code No & Fructose & Glucose & $\mathrm{F}+\mathrm{G}$ & $\mathrm{F} / \mathrm{G}$ & Sucrose \\
\hline HC1 & 39.71 & 27.91 & 67.62 & 1.42 & N.D. \\
HC2 & 41.82 & 28.21 & 70.03 & 1.48 & N.D. \\
HC3 & 40.94 & 28.86 & 69.80 & 1.42 & 1.63 \\
HC4 & 40.16 & 26.98 & 67.14 & 1.49 & N.D. \\
HK1 & 41.20 & 28.61 & 69.81 & 1.44 & 1.83 \\
HK2 & 40.33 & 27.82 & 68.15 & 1.45 & N.D. \\
HS1 & 38.35 & 30.77 & 69.12 & 1.25 & 1.61 \\
HS2 & 40.14 & 28.63 & 68.77 & 1.40 & N.D. \\
HS3 & 40.19 & 27.78 & 67.97 & 1.45 & N.D. \\
KD1 & 38.90 & 26.49 & 65.39 & 1.47 & 1.08 \\
KD2 & 39.79 & 31.54 & 71.33 & 1.26 & N.D. \\
KD3 & 35.72 & 28.62 & 64.34 & 1.25 & N.D. \\
KD4 & 38.56 & 26.28 & 64.84 & 1.47 & N.D. \\
KD5 & 37.39 & 24.63 & 62.02 & 1.52 & N.D. \\
KK1 & 38.56 & 26.15 & 64.71 & 1.47 & 1.73 \\
KK2 & 38.39 & 29.23 & 67.62 & 1.31 & N.D. \\
KU1 & 39.25 & 26.44 & 65.69 & 1.48 & N.D. \\
KU2 & 39.34 & 27.98 & 67.32 & 1.41 & 1.65 \\
KU3 & 39.08 & 29.36 & 68.44 & 1.33 & 1.42 \\
NK1 & 36.74 & 35.32 & 72.06 & 1.04 & N.D. \\
NK2 & 37.25 & 32.32 & 69.57 & 1.15 & N.D. \\
\hline
\end{tabular}


Table 3. Continues

\begin{tabular}{llllll}
\hline NK3 & 37.89 & 32.23 & 70.12 & 1.18 & 2.17 \\
NK4 & 37.19 & 33.27 & 70.46 & 1.12 & 1.99 \\
NK5 & 39.43 & 32.89 & 72.32 & 1.20 & N.D. \\
NK6 & 38.17 & 33.47 & 71.64 & 1.14 & N.D. \\
NK7 & 37.29 & 33.31 & 70.60 & 1.12 & 1.47 \\
NK8 & 39.47 & 34.32 & 73.79 & 1.15 & 1.65 \\
NF1 & 38.45 & 33.92 & 72.37 & 1.13 & N.D. \\
NF2 & 40.35 & 34.55 & 74.90 & 1.17 & 1.02 \\
NF3 & 37.26 & 32.28 & 69.54 & 1.15 & N.D. \\
NF4 & 38.16 & 29.89 & 68.05 & 1.28 & N.D. \\
NF5 & 38.56 & 28.34 & 66.90 & 1.36 & N.D. \\
PC1 & 34.23 & 28.71 & 62.94 & 1.19 & 1.99 \\
PC2 & 38.57 & 27.34 & 65.91 & 1.41 & 1.39 \\
PD1 & 39.19 & 26.34 & 65.53 & 1.49 & 1.08 \\
PD2 & 40.78 & 27.57 & 68.35 & 1.48 & 1.61 \\
PD3 & 40.47 & 27.63 & 68.10 & 1.46 & 1.73 \\
PK1 & 38.63 & 26.59 & 65.22 & 1.45 & 1.67 \\
PK2 & 39.56 & 26.81 & 66.37 & 1.48 & 1.81 \\
PK3 & 37.91 & 28.42 & 66.33 & 1.33 & 1.83 \\
\hline
\end{tabular}

\section{CONCLUSION}

According to the obtained results has been proved that all the used honey in the study shows the monofloral honey feature (more than 45\% dominant pollen). Moisture content of the honey samples analyzed was found at the expected values. The moisture content of thyme honeys was found to be less than the other honey's moisture content. This value shows that the thyme honey will last longer than the other honey. Because the moisture content, in time, causes the acidity of honey to increase and therefore increases the hydrolysis event in honey.

$\mathrm{pH}$ and acidity values of honey samples were found within TFC limits. According to these results, it was determined that citrus honey had the least acidity value compared to other honey. In addition, the acidity value of honey honeys was higher. Honey's $\mathrm{pH}$ and acidity values provide important information about its quality and condition.

As briefly described in section 3.4, the reason for the conductivity value of thyme and Heather honey is greater than $0.8 \mu \mathrm{S} / \mathrm{cm}$ due to the geographical position and time of collection of the region. There are thyme species such as Thymbra spicata, Origanum onites and Thymus cilicicus in the area where thyme honey are collected. There are intense pine trees in the area where thyme and heather plants are found. Since the collection of samples coincided with the early pine bark period, the sporophyte obtained by the Marcellina bug was observed in the results of palynological analysis carried out in small quantities except pollen. The mixing of these secretions with thyme and heather honeys caused an increase in the conductivity level.

As a result of the analyzes, it was determined that the honeys included in the study had monofloral properties. The physicochemical results of all honey samples were found to be compatible with the Turkish Food Codex and CODEX Alimentarious Commission Honey Standarts.

\section{Acknowledgements}

We thank the Scientific Research Projects Foundation of Selcuk University (SUBAP-Grant Number 2009/09101036) for financial.

\section{Orcid}

Sukru KARATAS (D) https://orcid.org/0000-0003-0348-1076 


\section{Abdurrahman AKTUMSEK (i) https://orcid.org/0000-0002-5151-2650}

Mehmet Emin DURU (D) https://orcid.org/0000-0001-7252-4880

\section{REFERENCES}

[1] Silva L.R., Videira R., Monteiro A. P., Valentão P., Andrade B. (2009). Honey from Luso region (Portugal): Physicochemical characteristics and mineral contents. Microchemical Journal, 93, 73-77.

[2] Karabagias I. K., Artemis P., Louppis A. P., Karabournioti S., Kontakos S., Papastephanou C., Kontominas M. G. (2017). Characterization and classification of commercial thyme honeys produced in specific Mediterranean countries according to geographical origin, using physicochemical parameter values and mineral content in combination with chemometrics. European Food Research Technology, 243, 889-900.

[3] El Sohaimy S. A., Masry S. H. D., Shehata M. G. (2015). Physicochemical characteristics of honey from different origins. Annals of Agricultural Science, 60, 279-287.

[4] CODEX Alimentarius Commission Standards. (2001). CODEX STAN. 12-1981, Rev. 1 (1987), Rev. 2., pp.1-7.

[5] Puscas A., Hosu A., Cimpoiu C. (2013). Application of a newly developed and validated high-performance thin-layer chromatographic method to control honey adulteration. Journal Chromatography A, 1272, 132-135.

[6] Mateo R \& Bosch-Reig F. (1998). Classification of Spanish Unifloral Honeys by Discriminant Analysis of Electrical Conductivity, Color, Water Content, Sugars, and pH. Journal of Agricultural and Food Chemistry, 46, 393-400.

[7] Terrab A., Díez M. J., Heredia F. J. (2002). Characterization of Moroccan Monofloral honeys by their physicochemical characteristics. Food Chemistry, 79, 373-379.

[8] Terrab A., Recalames A. F., Hernanz D., Heredia F. J. (2004). Characterisation of Spanish thyme honeys by their physicochemical characteristics and mineral contents. Food Chemistry, 88, 537-542.

[9] AOAC (Association of Official Analytical Chemists), 2005. Official Methods of Analysis 920.180. (18th Ed.); Honey (Liquid, Strained or Comb) Preparation of Test Sample, Inc.

[10] Bogdanov, S., Bieri, K., Figar, M., Figueiredo, V., Iff, D., Känzig, A., Stöckli, H., Zurcher, $\mathrm{K}$., definition et directives pour L'analyse et L'appreciation. In livre Suisse des denrees alimentaires, 1995, 1-26.

[11] Lazaridio, A. (2004). Composition, thermal and rheological behaviour of selected Grek honeys. Journal of Food Engineering, 64, 9-21.

[12] Özcan, M.M., Ölmez, Ç. (2014). Some qualitative properties of different monofloral honeys. Food Chemistry, 163, 212-218.

[13] Yanniotis, S., Skaltsi, S., Karaburnioti, S. (2006). Effect of moisture content on the viscosity of honey at different temperatures. Journal of Food Engineering, 72, 372-377.

[14] Özcan, M.M., Taştepe, B., Arslan, D., Ünver, A. (2013). Some qualitative properties of different monofloral honeys. Journal of Agroalimentary Processes and Technologies, 19, $355-361$.

[15] Sabo M., Potocnjak M., Banjarı I., Petrovic D. (2011). Pollen analysis of honeys from Varaždin County, Croatia. Turkish Journal Botany, 35, 581-587.

[16] Noor M. J., Ahmad M., Ashraf M. A., Zafar M., Sultana S. (2016). A review of the pollen analysis of South Asian honey to identify the bee floras of the region. Palynology, 40, 5465.

[17] Barth, O. M. (1990). Pollen in monofloral honeys from Brazil. Journal of Apicultural Research, 29, 89-94.

[18] Barth O. M. (2004). Melissopalynology in Brazil: A Review of Pollen Analysis of Honeys, Propolis and Pollen Loads of Bees. Scientia Agricola (Piracicaba Brazilya), 61, 342-350. 
[19] Louveaux J., Maurizio A., Vorwohl G. (1978). Methods of melissopalynology. Bee world, $59,139-157$.

[20] Sorkun, K. (2008). Türkiye'nin Nektarlı Bitkileri, Polenleri ve Balları. Palme Yayıncılık, s.4-9, Ankara.

[21] Acquarone, C., Buera P., Elizalde B. (2007). Pattern of pH and electrical conductivity upon honey dilution as a complementary tool for discriminating geographical origin of honeys. Food Chemistry, 101, 695-703.

[22] Anklam, E. (1998). A review of the analytical methods to determine the geographical and botanical origin of honey. Food Chemistry, 63, 549-562.

[23] Borsato D. M., Farago P. V., da Luz C. F. P., De Alencar S. M., De Almeida M. M. (2014). Physicochemical quality, botanical origin and antioxidant properties of floral honeys from Camp os Gerais region, Brazil. Interciencia, 39, 249-254.

[24] Nanda, V., Sarkar, B., Sharma, H., Bawa, A. (2003). Physicochemical properties and estimation of mineral content in honey produced from different plants in Northern India. Journal of Food Composition and Analysis, 16, 613-619.

[25] Azonwade F. E., Paraïso A., Tossou M. G., Sina H., Kelomey A. E., Chabi-Sika K., BabaMoussa L. (2017). Pollen Analysis of the Honeys Samples Produced in the Three PhytoGeographical Zones of Benin. European Scientific Journal, 13, 1857-1881.

[26] Cavia M. M., Fernandez-Muino M. A., Gomez-Alonso E., Montes-Perez M. J., Huidobro J. F., Sancho M. T. (2002). Evolution of fructose and glucose in honey over one year: influence of induced granulation. Food Chemistry, 78, 157-161.

[27] Truzzi C., Illuminatia S., Annibaldia A., Finalea C., Rossettib M., Scarponia G. (2014). Physicochemical Properties of Honey from Marche, Central Italy: Classification of Unifloral and Multifloral Honeys by Multivariate Analysis. Natural product communications, 9, 1595-1602.

[28] Kayacier A., \& Karaman S. (2008). Rheological and Some Physicochemical Characteristics of Selected Turkish Honeys. Journal of Texture Studies, 39, 17-27.

[29] Mendes E, Proenca E. B., Ferreira M. A. (1998). Quality evaluation of Portuguese honey. Carbohydrate Polymers, 37, 219-223.

[30] Turkish Food Codex. (2005). Türk Gida Kodeksi Yönetmeliği, Bal Tebliği No: 2005/49, Resmi Gazete 17.12.2005/26026. http://www.resmigazete.gov.tr/eskiler/2005/12/200512 17-9.htm

[31] Kuc J., Grochowalski A., Kostina M. (2017). Determination of the diastase activity in honeys. Technical Transactions, 8, 29-35.

[32] Can Z., Yildiz O., Sahin H., Akyuz Turumtay E., Silici S. Kolayli S. (2015). An investigation of Turkish honeys: Their physico-chemical properties, antioxidant capacities and phenolic profiles. Food Chemistry, 180, 133-141.

[33] Cotte J. F., Casabianca H., Giroud B., Albert M., Lheritier J., Grenier-Loustalot M. F. (2004). Characterization of honey amino acid profiles using high-pressure liquid chromatography to control authenticity. Analytical and Bioanalytical Chemistry, 378, 1342-1350.

[34] Bogdanov S. et al. (1999). Honey quality and international regulatory standards: review by the International Honey Commission. Bee World, 80, 61-69.

[35] da Silva P. M., Gauche C., Gonzaga L. V., Costa A.C.O., Fett R. (2016). Honey: chemical composition, stability and authenticity. Food Chemistry, 196, 309-323.

[36] de Sousa J.M.B, de Souza E.L, Marques G., de Toledo Benassi M., Gullon B., Pintado M., Magnani M. (2016). Sugar profile, physicochemical and sensory aspects of monofloral honeys produced by different stingless bee species in Brazilian semi-arid region. Food Science and Technology, 65, 645-651. 